\title{
Application of Discovery Learning Model to Improve the Understanding Concept of High School Students on Buffer Topic
}

\author{
*Nurfauzia, ljirana \& Suherman \\ Chemistry Education / FKIP - Tadulako University, Palu - Indonesia 94119 \\ Received 09 December 2020, Revised 13 January 2021, Accepted 10 February 2021 \\ doi: $10.22487 / j 24775185.2021 . v 10 . i 1 . p p 26-31$
}

\begin{abstract}
This study aimed to describe the increase in understanding of students in class XI SMA 7 Palu on the buffer solution material after applying the discovery learning model. This type of research was pre-experiment with the design of one group pre-test-post-test. This study was conducted in two replication classes, namely, class XI MIA 1 as replication class $1(n=26)$ and class XI MIA as replication class $2(n=24)$. Testing of the data from research results data used descriptive statistical analysis of the understanding concept. The criteria for understanding the concept was good if the percentage of students who have the category of moderate, high, and very high is not less than $60 \%$. The data results of analysis understanding of each concept obtained in the replication class 1 . The concept of buffer, score $65.38 \%$ increased to $96.15 \%$. The concept of the properties of the buffer score $3.84 \%$ increased to $96.15 \%$. The concept of acid-base buffer solution, score 0\% increased to 92.3\%. The concept of pH acid buffer, score $0 \%$ increased to $88.46 \%$. The concept of $p H$ base buffer, score $0 \%$ increased to $84.61 \%$. In replication class 2, the concept of buffer solution score is $20.83 \%$, increased to $91.66 \%$. The concept of acid and base buffer solution, score $12.5 \%$ increased to $91.66 \%$. The concept of $p H$ base buffer, score $4.16 \%$ increased to $83.33 \%$. The results of the analysis showed that there is an increase in understanding the good concept by applying the discovery learning model in the buffer material.
\end{abstract}

Keywords: Discovery Learning, understanding concepts, buffer.

\section{Introduction}

Chemistry is a branch of natural science in which many studies matter and its changes. Chemistry is fundamental because it is closely related to everyday life and has many benefits for humans. However, according to Sunyono (2016), there are many facts that show that chemistry is seen as a problematic and unattractive science to study. This is also supported by Caster and Brickhouse's statement in Afadil \& Diah (2017), which stated that the majority of students consider chemistry a complex subject.

The difficulties of students in learning chemistry resulted in many students experiencing failures in studying chemistry. Sirait \& Hutabarat (2015) stated that the difficulty of students understanding and applying chemical concepts causes students to take the fastest steps by memorizing. This difficulty in chemistry is related to the characteristics of chemistry itself. According to Yakina et al. (2017) that most chemistry is abstract. This is also supported by research by Marsita et al. (2010), who argues that what causes difficulties in studying chemical materials is the characteristics of the material, which are primarily abstract.

The results of an interview conducted with one of the teachers at SMA Negeri 7 Palu said that, in general, students had difficulty understanding concepts. The lack of understanding of these concepts is probably the main factor causing students difficulties in solving reaction equations and mathematical calculations in chemistry learning materials. One of them is in the buffer material. This is seen from the lack of students' ability to distinguish between the determination of the $\mathrm{pH}$ of the acid buffer solution and the alkaline buffer solution so that it has an impact on students' scores, which are about $75 \%$ of students who are below the minimum completeness criteria standard (KKM).

One of the chemical materials that requires an understanding of the concept is the buffer solution material. According to Isnaini et al. (2015) stated that the buffer material is one of the materials which most of the concepts are quite complicated, for example determining the $\mathrm{pH}$ of a buffer solution that is slightly acidic or wet. Students must master

*Correspondence

Nurfauzia

e-mail: nurfauzia803@gmail.com

(c) 2021 the Author(s) retain the copyright of this article. This article is published under the terms of the Creative Commons Attribution License 4.0, which permits unrestricted non-commercial use, distribution, and reproduction in any medium, provided the original work is properly cited. 
the precondition concept to understand the material of buffer solutions, namely the acid-base concept according to Bronsted Lowry, acid-base reaction equations, and other concepts.

The phenomenon of teaching that does not involve students directly in teaching and learning activities causes students to have less psychomotor and affective abilities. Students rarely discuss and cooperate with other students resulting in students becoming passive. This is supported by the results of research Tambunan \& Bukit (2015), which state that the level of understanding of the concept by applying the direct instruction learning model is lower than the level of understanding by applying a model that involves students in the learning process. Therefore, teachers as educators need to create innovation, namely by choosing a strategy or way of conveying the material in order to obtain an increase in student understanding of concepts. For example by guiding students together to be actively involved in the learning process and helping students develop thinking skills according to their intellectual level will further strengthen students' understanding of the concepts being taught (Balim, 2009).

One of the things that the researcher thinks can solve this problem is the application of the discovery learning model. Discovery learning refers to learning that occurs when students are involved in experiences, where they gain their own knowledge and concepts (Mubarok \& Sulistiyo, 2014).

According to Hamalik (2003), the discovery learning model emphasizes the importance of understanding a concept through active student involvement in the learning process. This learning model emphasizes the formation of student knowledge from experience during learning. Learning activities by means of this discovery can increase students' interest in learning chemistry in a way that is more fun than conventional methods. In science lessons, activities, which are based on inquiry using the discovery learning method, can be used with the aim of attracting students' attention and enabling them to participate more in class (Zuljafri, 2016).

The stages in the implementation of the discovery learning model include stimulus, statement problems, data collection, data processing, verification, and the last stage is a generalization (Kurniasih \& Sani, 2014). In the data processing stage, a conceptual understanding can be formed, especially in the material of the buffer solution, such as understanding the concept of a buffer solution, the concept of an acid buffer solution, an alkaline buffer solution, and the concept of $\mathrm{pH}$ of a buffer that is added a little acid or base. It is hoped that the application of discovery learning models can improve students' understanding of the concept of the buffer material. According to Mahmoud (2014), the discovery learning model helps obtain activities where students learn for themselves and apply what they know in new situations, which will lead to effective learning achievement. The purpose of the present paper is to describe the application of the discovery learning model to improve students' understanding of learning concepts in the material of buffer class XI SMA Negeri 7 Palu.

\section{Methods}

The method used in this research is preexperimental method with research design one group pre-test-post-test design. The subjects of this study were 26 students in the replication class 1 and 24 students in the replication class 2 at SMA Negeri 7 Palu, the instruments used were multiple choice questions and the learning implementation observation sheet.

\section{Results and Discussion}

\section{Analysis of the Learning Implementation Observation Sheet}

The results of the study of the observation sheet for the implementation of learning in class replication 1 and class replication 2 at each meeting. The results obtained are presented in Table 1.

Table 1 The percentage of the results of the analysis of the learning implementation observation sheet

\begin{tabular}{ccc}
\hline \multirow{2}{*}{ Meeting } & \multicolumn{2}{c}{ Percentage (\%) } \\
& Replication Class 1 & Replication Class 2 \\
\hline Meeting 1 & 100 & 100 \\
Meeting 2 & 100 & 96 \\
Meeting 3 & 100 & 100 \\
\hline Average & 100 & 98 \\
\hline \hline
\end{tabular}

Based on the Table 1, it shows that the implementation of learning in replication class 1 is $100 \%$ carried out, while the implementation of learning in replication class 2 is $98 \%$ carried out.

Based on the results obtained in Table 1 , it shows that from the first to the last meeting in class 1 replication $100 \%$ was carried out, but in replication class 2 it was only done $98 \%$. The application that was not carried out properly was at the second meeting with the sub-material for determining the $\mathrm{pH}$ of the buffer solution. The presentation of teaching material that is not in 
accordance with the steps contained in the RPP and the mismatch of the evaluation time allocation with the time allocation in the RPP. This is due to the lack of understanding of the students' initial concepts of determining $\mathrm{pH}$, especially in doing mathematical calculations. In the learning process, a lot of time is spent in completing the $\mathrm{pH}$ calculation of the buffer solution, resulting in insufficient time spent evaluating. This also happened in the research of Sukawati et al. (2016).

One thing that must be considered in the application of discovery learning is that teachers must be competent in managing student learning time to suit the steps of this method (Susanti et al., 2016). The limited learning time is a drawback of the discovery learning model, as Hosnan (2014) stated that one of the shortcomings of the discovery learning model is it takes up a lot of time because teachers are required to change their teaching habits, who generally act as information givers, into facilitators, motivators, and mentors.

The unfamiliarity of students being directly involved in the learning process is also a significant factor in this research. Especially in obtaining learning resources because previously learning was only teacher-centered or, in other words, the teacher dominated learning, the teacher delivered more material directly to students, which resulted in students having difficulty developing their own concepts. According to Tambunan \& Bukit (2015), the phenomenon of teaching that does not involve students directly in teaching and learning activities causes students to lack psychomotor and affective abilities. Students rarely discuss and cooperate with other students, which results in students becoming passive. Apart from these factors, the researcher lacks the ability to manage the class as a major factor.

\section{Descriptive Statistical Analysis of Conceptual Understanding \\ Concept understanding is a person's} ability to understand or understand something that has been known or remembered (Rahmi et al., 2015). Students can be said to understand the concept if they can solve concept understanding test questions, as is Qashdi (2016) states that the student's ability to understand a chemical concept is crucial in the process of solving chemical problems.

The following is the percentage of the results of the analysis of the number of students who have a moderate minimum concept understanding category obtained from scoring each concept can be seen in Table 2 and 3.

Table 2 The percentage of the results of the analysis of the number of students which has a minimum category of understanding the concept of being replicated class 1

\begin{tabular}{ccc}
\hline Concept & Pre-test & Post-test \\
\hline a & 65.38 & 96.15 \\
b & 3.84 & 96.15 \\
c & 0.00 & 92.30 \\
d & 0.00 & 88.46 \\
e & 0.00 & 84.61 \\
\hline
\end{tabular}

Table 3 The percentage of the results of the analysis is the number of students who have a minimum category of understanding the concept of being in replication class 2

\begin{tabular}{ccc}
\hline Concept & Pre-Test & Post-Test \\
\hline $\mathrm{a}$ & 20.83 & 91.66 \\
$\mathrm{~b}$ & 0.00 & 8.33 \\
$\mathrm{c}$ & 12.50 & 91.66 \\
$\mathrm{~d}$ & 0.00 & 33.33 \\
$\mathrm{e}$ & 4.16 & 83.33 \\
\hline
\end{tabular}

Based on these data, a comparison of increased understanding between the pre-test and post-test for each concept can be seen in Figure 1. Information:

$$
\begin{aligned}
& \text { a : buffer solution concept } \\
& \text { b : the concept of the properties of the buffer } \\
& \text { solution }
\end{aligned}
$$
c : the concept of acid and base buffer solutions
$\mathrm{d} \quad$ : the concept of $\mathrm{pH}$ of an acid buffer solution
e : the concept of $\mathrm{pH}$ of an alkaline buffer solution

The comparison of the percentage of students' concept understanding was obtained by each student (SS) in the replication class 1 , 
namely the buffer solution concept $65.38 \%$ increased to $96.15 \%$, the concept of the properties of the buffer solution $3.84 \%$ increased to $96.15 \%$, the concept of $0 \%$ acid and base buffer solutions increases to $92.3 \%$, in the concept of $0 \%$ acid buffer solution $\mathrm{pH}$ increases to $88.46 \%$, in the concept of $0 \%$ alkaline buffer solution $\mathrm{pH}$ increases to $84.61 \%$. The percentage of students' understanding of the concept was obtained by each student (SS) in the second replication class, namely the buffer solution concept $20.83 \%$ increase $91.66 \%$, the concept of the properties of the buffer solution $0 \%$ increased to $8.33 \%$, the concept of a $12.5 \%$ acid and base buffer solution increases to $91.66 \%$, the $\mathrm{pH}$ concept of a $0 \%$ acid buffer solution increases to $33.33 \%$, the concept of $\mathrm{pH}$ of $4.16 \%$ alkaline buffer solution increases to $83.33 \%$. Based on the results of these percentages, in the replication class 1 to 5 the concepts were categorized as an increase in concept understanding because the percentage of understanding each concept was more than 60\% (Ijirana, 2016).

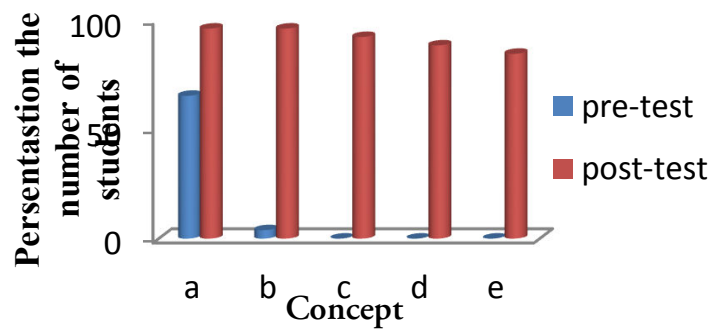

Figure 1. Increasing understanding of each replication class concept 1

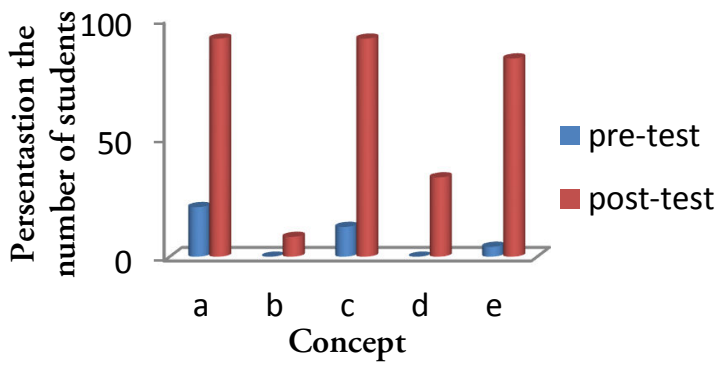

Figure 2. Increasing understanding of each replication class concept 2

The understanding of the good concepts obtained in class replication 1 can be seen from the learning process at the first meeting to the third meeting, where at the first meeting through the stimulus provided by the researcher, students can find for themselves the concepts of understanding and components of the buffer solution through group discussions. At the second meeting, the students seemed more active than in the previous meeting. There were some students who asked questions about things they had not understood, and some students began to enthusiastically respond to the results of discussions from other groups. At the third meeting, most of the students were also active in group discussions and class discussions. This shows that slowly students begin to get used to the learning model that is applied. This is in accordance with the statement of Novayani et al. (2015), which states that when students are motivated and do participate in discovery, discovery learning will lead to an excellent learning process. However, in replication class 2, the learning process was not as active as students in replication class 1 , so that it affected students' final conceptual understanding because knowledge and understanding were a strength to be able to work on and solve a problem (Hunt, 2003).

Improved understanding of good concepts in replication class 2 is only on the concept of buffer solutions, the concept of acid and base buffer solutions, and the concept of $\mathrm{pH}$ of alkaline buffer solutions, while for the concept of the properties of buffer solutions and $\mathrm{pH}$ of acid buffer solutions cannot be categorized well because the presentation of understanding the concept is less than $60 \%$ namely $8 \%$ and $54 \%$, This shows that there are external (environmental) factors that affect students' understanding of concepts, such as different student conditions. Not all students can follow lessons using model discovery learning (Hosnan, 2014). 
Based on the data obtained, the descriptive test of conceptual understanding shows that the application of the discovery learning model can improve students' conceptual understanding. This is in accordance with Istiana et al. (2015), namely, model discovery learning can improve student achievement in cognitive, affective, and psychomotor aspects.

\section{Conclusion}

There is an increase in understanding of the concept before and after the application of the discovery learning model, namely in replication class 1 especially on the concept of buffer solutions $65.38 \%$ increased to $96.15 \%$, the concept of the properties of the buffer solution $3.84 \%$ increased to $96.15 \%$, the concept of $0 \%$ acid and base buffer solutions increases to $92.3 \%$, in the concept of $0 \%$ acid buffer solution $\mathrm{pH}$ increases to $88.46 \%$, in the concept of $0 \%$ alkaline buffer solution $\mathrm{pH}$ increases to $84.61 \%$. In class 2 replication is the concept of a buffer solution $20.83 \%$ increase $91.66 \%$, the concept of a $12.5 \%$ acid and base buffer solution increased to $91.66 \%$, in the concept of an alkaline buffer solution $\mathrm{pH}$ of $4.16 \%$ increased to $83.33 \%$.

\section{Acknowledgments}

The author's gratitude gives to the Chemistry Education Study Program, Faculty of Teacher Training and Education, Tadulako University, and all those who helped the author a lot in completing this research.

\section{Reference}

Afadil, \& Diah, A. W. M. (2017). Effectiveness of learning materials with science-philosophy oriented to reduce misconceptions of students on chemistry, Proceeding of of the First Indonesian Communication Forum of Teacher Training and Education Faculty Leaders International Conferences on Education 2017 (pp 192-196). Belanda: Atlantis Press.

Balım, A. G. (2009). The effects of discovery learning on students' success and inquiry learning skills. Eurasian Journal of Educational Research, 35, 1-20.

Hamalik, O. (2003). Perencanaan pengajaran. Jakarta: Bumi Aksara.

Hosnan, M. (2014). Pendekatan saintifik dan kontekstual dalam pembelajaran abad 21. Jakarta: Ghalia Indonesia.

Hunt, D. W. (2003). The concept of knowledge and how to measure it. Journal of Intellectual Capital, 4(1),110-113.

Ijirana. (2016). Model pembelajaran berbasis keterampilan metakogniif (model pbkm) untuk meningkatkan kemampuan pemecahan masalahan pemahaman konsep kimia mahasiswa pendidkan kimia. Disertasi Tidak
Diterbitkan Surabaya: Universitas Negeri Surabaya.

Isnaini, Masriani, \& Sartika, R. P. (2015). Pemahaman konsep materi larutan penyanga menggunakan two-tier multiple choice diagnostic instrument di SMA. Journal of Chemical Education, 4(12), 1-11.

Istiana, G. A., Catur, A. N., \& Sukardjo, J. S. (2015). Penerapan model pembelajaran discovery learning untuk meningkatkan aktivitas dan prestasi belajar pokok bahasan larutan penyangga pada siswa kelas XI IPA semester II SMA Negeri 1 Ngemplak tahun ajaran 2013/2014. Journal of Chemical Education, 4(2), 65-73.

Kurniasih, I., \& Sani, B. (2014). Sukses mengimplementasikan kurikulum 2013. Jakarta: Kata Pena.

Mahmoud, K. A. R. (2014). The effect of using discovery learning strategy in teaching grammatical rules to first year general secondary student on developing their achievement and metacognitive skills. International Journal of Innovation and Scientific Research, 5(2), 146-153.

Marsita, R. A., Priatmoko, S., \& Kusuma, E. (2010). Analisis kesulitan belajar siswa kimia siswa SMA dalam memahami materi larutan penyangga dengan menggunakan two-tier multiple choice diagnostic instrument. Jurnal Inovasi Pendidikan Kimia, 4(1), 512-520.

Mubarok, C., \& Sulistiyo, E. (2014). Penerapan model pembelajaran discovery learning terhadap hasil belajar siswa kelas x tav pada standar kompetensi melakukan instalasi sound system di SMK Negeri 2 Surabaya. Jurnal Pendidikan Tehnik Elektro, 3(2), 215 221.

Novayani, S., Nufida, B. A., \& Mashami, R. A. (2015). Pengaruh model discovery learning terhadap keterampilan berpikir kritis siswa SMP pada materi pencemaran lingkungan. Jurnal Ilmiah Pendidikan Kimia, 3(1), 253 258.

Qashdi, A. (2016). Pengaruh penerapan model pembelajaran kooperatif tipe think pair share (tps) dengan menggunakan media prezi dekstop terhadap pemahaman konsep kimia siswa SMA Negeri 1 Kampar. Skripsi Tidak Diterbitkan. Pekanbaru: Universitas Islam Negeri Sultan Syarif Kasim Riau Pekanbaru.

Rahmi K. F., Sahputra R., \& Sartika. R. P. (2015). Pengaruh model guided discovery learning pada larutan penyangga (buffer) terhadap pemahaman konsep siswa SMA. Journal of Chemical Education, 4(8), 1-13.

Sirait, T., \& Hutabarat, W. (2015). Pengaruh model pembelajaran problem-based learning dengan media power point terhadap hasil belajar kimia siswa SMA pada pokok bahasan 
konsep redoks. Jurnal Pendidikan Kimia, $7(2), 1-7$.

Sukawati, D. T., Rosilawati, I., \& Efkar, T. (2016). Efektifitas discovery learning pada larutan penyangga dalam meningkatkan keterampilan mengelompokkan dan mengkomunikasikan. Jurnal Pendidikan dan Pembelajaran Kimia, 5(3), 27-38.

Sunyono. (2016). Identifikasi masalah kesulitan dalam pembelajaran kimia kelas X di Provinsi Lampung. Journal of Chemical Education, 13(10), 33-42.

Susanti E., Jamhari M., \& Suleman, S. M. (2016). Pengaruh model pembelajaran discovery learning terhadap keterampilan sains dan hasil belajar siswa kelas viii tentang ipa SMP Advent Palu. Jurnal Sains dan Teknologi Tadulako, 5(3), 36-41
Tambunan, E., \& Bukit, N. (2015). Analisis pengaruh model pembelajaran kooperatif tipe group investigation dan pemahaman konsep awal terhadap hasil belajar siswa di SMA Negeri 1 Teluk Mengkudu. Jurnal Pendidikan Fisika Pascasarjana Universitas Negeri Malang, 4(1), 49-56.

Yakina, Kurniati, T., \& Fadhilah, R. (2017). Analisis kesulitan belajar siswa pada mata pelajaran kimia kelas $\mathrm{X}$ di SMA negeri 1 sungai Ambawang. Journal of Chemical Education, 5(2), 287-297.

Zuljafri, M., \& Amelia, R. (2016). Pengaruh model discovery learning dengan media tekateki silang terhadap peningkatan hasil belajar siswa pada materi sistem koloid. Journal of Chemical Education, 1(1), 12-18. 